\title{
CHARACTERIZATION OF ANABAENA AZOLLAE ISOLATED FROM AZOLLA PINNATA
}

\author{
Azza A. M. Abd El-AAI \\ Soils, Water and Environment. Res. Inst., ARC, Giza, Egypt \\ (Manuscript received 20 March 2013)

\begin{abstract}
A symbiotically associated cyanobacterium (Anabaena azollae) was isolated from Azolla pinnata and cultured under a free-living state. It is characterized by filamentous brown to olive in color culture, its vegetative cells are cylindrical and their diameters ranged from 8 to $9 \mu \mathrm{m}$ width and from 5 to $6 \mu \mathrm{m}$ length. Heterocysts were found to be internal and terminal in the filament, its shape is spherical and its diameters ranged from 9 to $9.5 \mu \mathrm{m}$ width and from 9 to $9.5 \mu \mathrm{m}$ length. Akintes are present with cylindrical shape, with diameters of 9-10 $\mu \mathrm{m}$ width and 6-8 $\mu \mathrm{m}$ length. Nitrogenase activity of Anabaena azollae increased gradually from 0.1786 to $4.7992 \mu$ mole $\mathrm{C}_{2} \mathrm{H}_{4} \mathrm{~g}$ soil/hr along 4 weeks. The strain showed high efficacy in suppressing the fungal mycelial growth of either Fusarium oxysporum or Alternaria alternate by $100 \%$.
\end{abstract}

\section{INTRODUCTION}

Azolla is a free-floating water fern that floats on the water and fixes atmospheric nitrogen in association with the nitrogen fixing cyanobacterium Anabaena azollae. Azolla-Anabaena symbiosis is the only plant-cyanobacterial symbiosis used as biofertilizer in agriculture. Anabaena azallea is a prokaryotic, filamentous nitrogen fixing cyanobacterium that is symbiotically associated with the small eukaryotic water from Azolla pinnata. The endosymbiont is contained within specialized leaf cavities of the fern under natural conditions.

Cyanobacteria-free Azolla spp. are generally not found in nature, but cultures have been generated by a variety of methods for use in laboratory studies, one of the most frequently used methods is antibiotic treatment( Peters and Mayne, 1974). Cyanobacteria from the symbiosis have also been isolated and cultured independently of the fern (Subramanian and Malliga, 1988). Researchers have noted that although the free-living isolates of Anabaena azollae are closely resemble to Anabaena or Nostoc spp. in their general morphologies (Zimmerman et. al., 1989). The in vitrocultured filaments are morphologically distinct from filaments freshly removed from the fern cavity (Newton and Herman, 1979). Cyanobacteria have been identified as a new and rich source of bioactive compounds (Dahms et. al., 2006), belong to groups of polyketides, amides, alkaloids, fatty acids, indoles and lipopeptides were isolated 
(Abarzua et. al., 1999 and Burja et. al., 2001).Therefore the present study show the morphological characteristics of Anabaena azolae isolated from Azolla pinnata ,can be grown successfully free in BG11 medium and used as bioagent suppressor for the pathogenic fungi of Fusarium oxysporum and Alternaria alternate.

\section{MATERIALS AND METHODS}

\section{Preparation of Azolla pinnata}

Azolla pinnata was kindly provided by Agric. Microbiology Res. Dept., Soils, Water and Environment. Res. Inst., ARC, Giza, Egypt. Azolla was grown under the greenhouse conditions up to log phase on Yoshida medium (Yoshida et. al., 1976). (Plate1).

\subsection{Isolation of Anabaena azollae from Azolla pinnata}

Ten grams of fresh azolla were ground in crucible to squeeze the cells forming suspension and $5 \mathrm{~cm}$ from it was put in a $100 \mathrm{ml}$ conical flask containing BG11 medium (Rippika et. al., 1979) and incubated in a growth chamber under continuous illumination (2000 lux) and a temperature of $25^{\circ} \mathrm{C} \pm 2^{\circ} \mathrm{C}$. After 30 days of incubation, the developed cyanobacterial cells were cultured on Petri dishes (plate2) with BG11 agarized medium. Plates were incubated in an illuminated growth chamber for colony development. One of the developed cyanobacteria colonies was taken with a sterilized inoculation needle to be inoculated to conical flask containing liquid BG11 medium and reincubated in the illuminated growth chamber till the complete development of Anabaena azollae filaments growth after one month (plate 3).

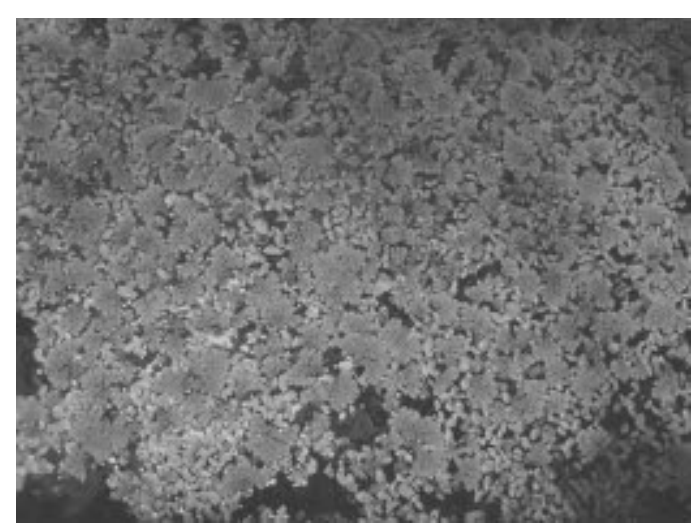

Plate 1. Azolla pinnata 


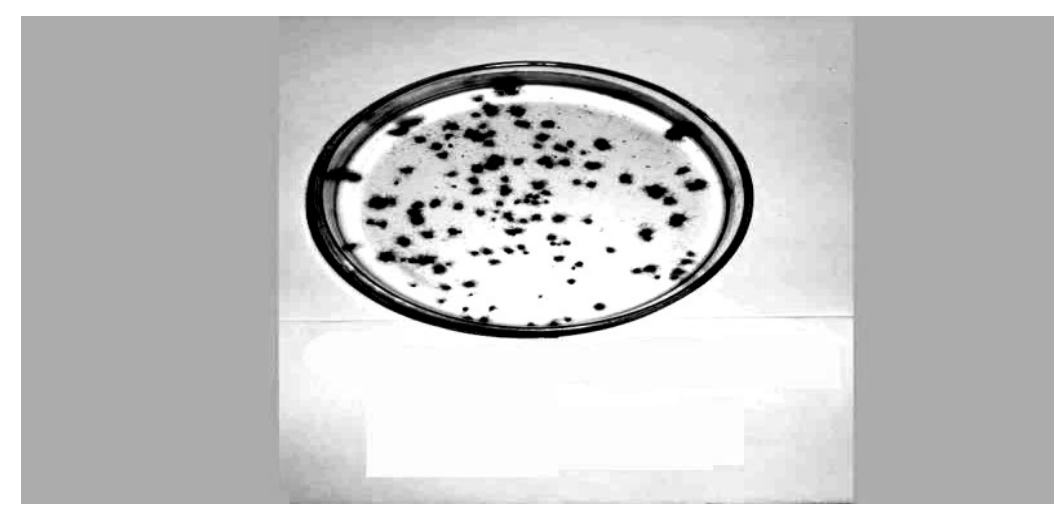

Plate 2. Anabaena azollae colonies isolated from Azolla pinnata on Petri dishes with BG11 agarized medium.

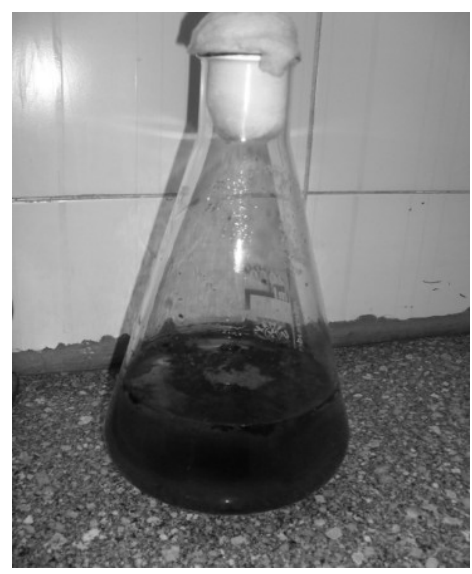

Plate 3. growth of Anabaena azollae free in BG11medium

\subsection{Identification of Anabaena isolate}

The isolate Anabaena was examined under the light microscope (power of microscope $1250 \mathrm{x}$ ). The shape and color of isolate culture, width and length of vegetative cells, presence or absence of heterocystes, site of heterocysts in filaments as well as shape, width and length of heterocystes, p6resence or absence of akinetes, shape, width and length of akinetes, were described and measured (Desikachary,1959).

\section{Nitrogenase activity}

The efficiency of Anabaena azollae to fix atmospheric nitrogen ( $\mathrm{N}_{2}$-ase activity) was assayed. The enzyme activity was estimated using the acetylene reduction technique (ARA) according to standard procedure described by Hardy et al. (1973).

\section{Culture filtrate preparation of Anabaena azollae}

The cultures were incubated in growth chamber under continuous illumination (2000 lux) at a temperature of $25^{\circ} \mathrm{C} \pm 2^{\circ} \mathrm{C}$. After 30 days of incubation, cultures were homogenized and filtered through Wathman No.1 paper and the filtrate was filter- 
sterilized through $0.45 \mu \mathrm{m}$ filter membrane and antibiotic treatment (Peters and Mayne, 1974).

\subsection{Fungus preparation}

The tested fungi (Fusarium oxyspora and Alternaria alternate ) were obtained from the Dept. of Survey and Identification of Fungal, Plant Pathol. Res. Inst., ARC, Giza, Egypt. The fungal strains were sub-cultured using fresh potato dextrose agar (PDA) (Difco, 1984) and stored in an incubator at $25^{\circ} \mathrm{C} \pm 1^{\circ} \mathrm{C}$.

\section{2 in vitro bioassay test of antifungal activity}

The prepared Anabaena Azollae culture filtrate was tested against pathogenic fungi of Fusarium oxysporum and Alternaria alternate previously grown in Petri dishes containing PDA and incubated for 10 days. The algal culture filtrate was used for evaluating the efficacy of algal antifungal activity.

Algal culture filtrate was prepared in flask containing PDA medium then poured into Petri dishes at the rate of $20 \mathrm{ml} /$ dish. Plates containing PDA media without algal culture filtrate were used as a control. Disks ( $5 \mathrm{~mm}$ diameter) were taken individually from the developed fungal growth cultures; each was placed in the centre of each Petri dish. Five Petri dishes were used as replicates for each particular treatment as well as a control. Inoculated Petri dishes were incubated at $25^{\circ} \mathrm{C} \pm 1^{\circ} \mathrm{C}$ for 10 days then the average diameter of linear fungus growth was calculated. The inhibitory effect of algal culture filtrates on the radial mycelial growth of both Fusarium oxysporum and Alternaria alternata was evaluated.

\section{RESULTS AND DISCUSSION}

Table 1. Morphological characteristics of the cyanobacteria strain Anabaena azollae

\begin{tabular}{|c|c|c|c|c|c|c|c|c|c|c|c|}
\hline \multirow{2}{*}{$\begin{array}{c}\text { Color } \\
\text { of } \\
\text { Culture }\end{array}$} & \multirow{2}{*}{$\begin{array}{l}\text { General } \\
\text { shape }\end{array}$} & \multicolumn{3}{|c|}{ Vegetative Cel I } & \multicolumn{3}{|c|}{ Heterocyst } & \multirow{2}{*}{$\begin{array}{c}\text { Site of } \\
\text { Heterocyst }\end{array}$} & \multicolumn{3}{|c|}{ Akinetes } \\
\hline & & Shape & $\begin{array}{l}\text { Width } \\
(\mu \mathrm{m})\end{array}$ & $\begin{array}{l}\text { Length } \\
(\mu \mathrm{m})\end{array}$ & Shape & $\begin{array}{l}\text { Width } \\
(\mu \mathrm{m})\end{array}$ & $\begin{array}{l}\text { Length } \\
(\mu \mathrm{m})\end{array}$ & & Shape & $\begin{array}{l}\text { Width } \\
(\mu \mathrm{m})\end{array}$ & $\begin{array}{l}\text { Length } \\
(\mu \mathrm{m})\end{array}$ \\
\hline $\begin{array}{c}\text { Brown } \\
\text { to } \\
\text { Olive }\end{array}$ & Filamentous & Cylindrical & 8-9 & $5-6$ & Spherical & $9-9.5$ & $9-9.5$ & $\begin{array}{l}\text { Inter.\& } \\
\text { Ter.* }\end{array}$ & Cylindrical & $9-10$ & 6-8 \\
\hline
\end{tabular}

Table 1 showed that Anabaena azollae isolated from Azolla pinnata is characterized by filamentous brown to olive in color culture (plates 4 and 5) the shape of its vegetative cells is cylindrical and their diameters ranged from 8 to $9 \mu \mathrm{m}$ width and from 5 to $6 \mu \mathrm{m}$ length. Heterocysts are present and their sites are found to be 
internal and terminal in the filament, shape is spherical with diameters of 9 to $9.5 \mu \mathrm{m}$ width and 9 to $9.5 \mu \mathrm{m}$ length. Akintes are present and their shapes are cylindrical, their diameters ranged from 9 to $10 \mu \mathrm{m}$ width and 6 to $8 \mu \mathrm{m}$ length. Taxonomically, the Azolla cyanobiont is placed in phylum- Cyanophyta, Order-Nostocales, FamilyNostocaceae. It was first described as Nostoc and later renamed Anabaena azollae .

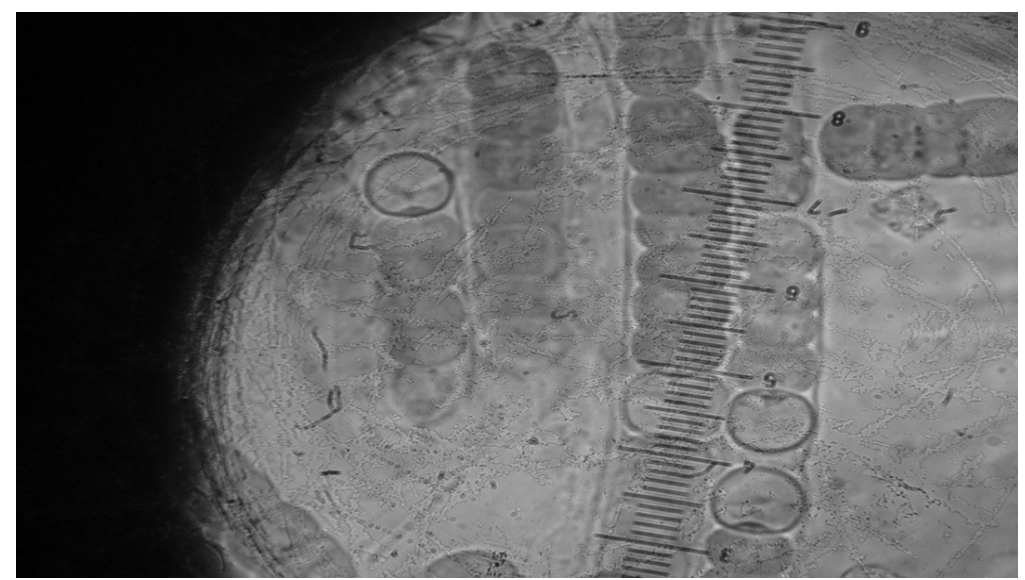

Plate. 4. Microscopic examamination of Anabaena azollae filaments.

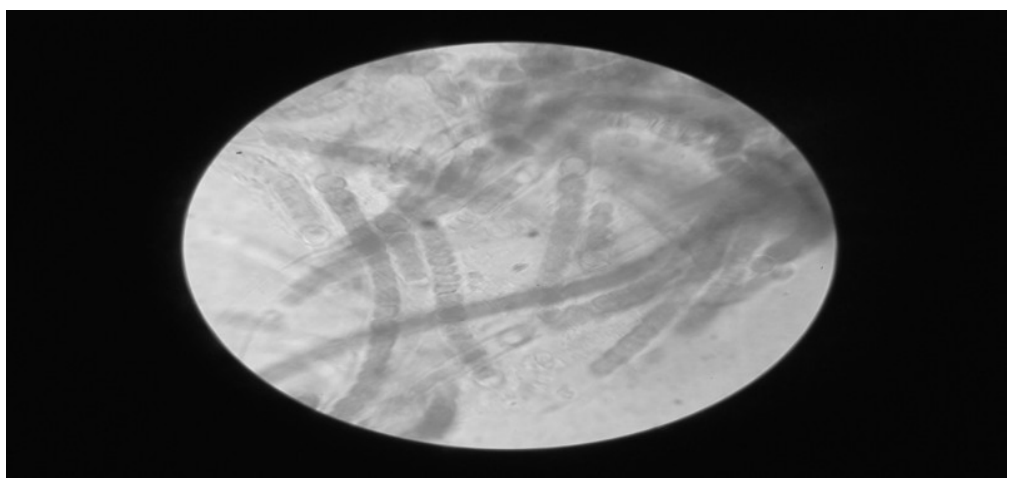

Plate. 5. Cells in Anabaena azollae grown in BG11 medium

\section{Nitrogenase activity}

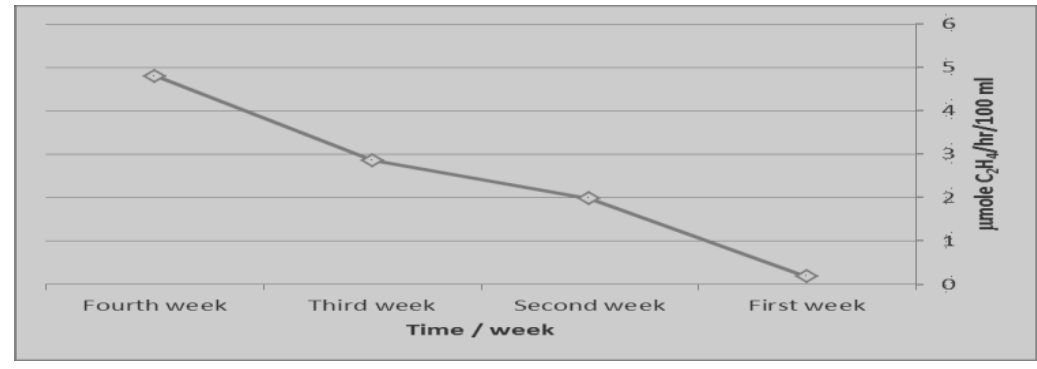

Figure1. Nitrogenase activity of Anabaena azollae during 4 weeks. 
Figure 1 showed that nitrogenase activity of Anabaena azollae increased gradually from 0.1786 to $4.7992 \mu$ mole $\mathrm{C}_{2} \mathrm{H}_{4} / \mathrm{g} /$ soil $/ \mathrm{hr}$ with increasing the incubation period from 1 to 4 weeks in BG11 medium. Pabby et al (2000) observed that in Azolla microphylla, ammonia assimilatory enzymes achieved highest activity at 24 hours after incubation in a medium containing urea and decreased thereafter. However, prolonged incubation for more than 14 days, in a medium containing different levels of nitrate, led to suppression of nitrogenase activity in Anabaena microphylla and Anabaena pinnata (Pabby et al.2001).

\section{Antifungal Activity of Anabaena Azollae}

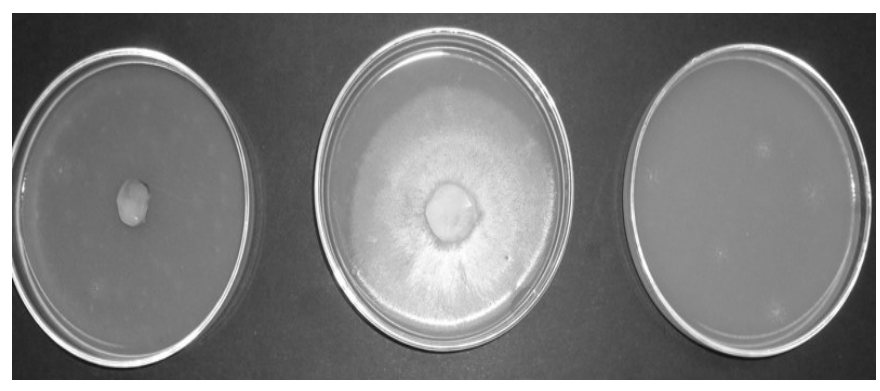

A

B

C

Plate 6. Antibiosis among Anabaena Azollae and Fusarium oxysporum AAnabaena Azollae + Fusarium oxysporum, $B^{-}$(control) Fusarium oxysporum C- (Control) Anabaena Azolla

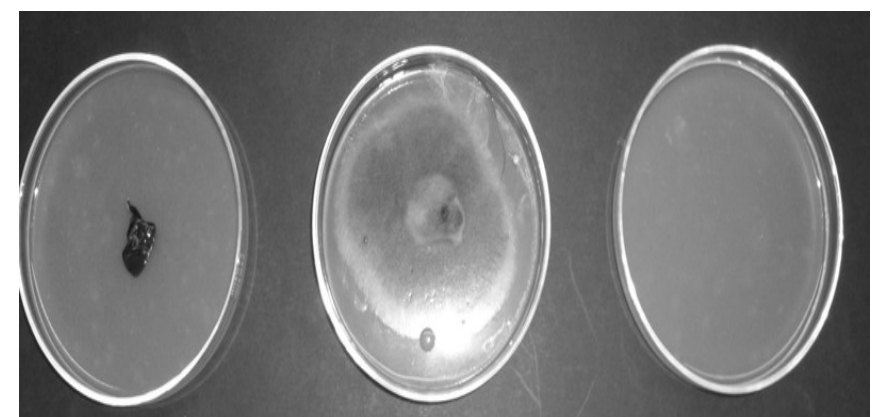

A

B

C

Plate 7. Antagonistic activity of Anabaena azollae towards A- Anabaena Azollae + Alternaria alternat, B- (Control) Alternaria alternat, C- (Control) Anabaena azollae 
Anabaena azollae inhibited the mycelial growth of both Fusarium oxysporum and Alternaria alternate and showed the highest efficacy in suppressing the fungal mycelial growth diameter by $100 \%$ as shown in plates 6 and 7. In this context, various strains of cyanobacteria are known to produce intracellular and extracellular metabolites with diverse biological activities such as antibacterial and antifungal effects. (Ghasemi et. al., 2007 ). Several attempts to recombine isolated anabaena azollae with cyanobacterium-free Azolla were reported to be unsuccessful (Liu et. al., 1984).

In conclusion, this study indicated the morphological charctaristices of Anabaena azollae isolated from Azolla pinnata and it can be free cultured in BG11 medium, as well as, it can be used, as a bioagent suppressor for the pathogenic fungal members Fusarium oxysporum and Alternaria alternate.

\section{REFERENCES}

1. Abarzua, S., S. Jakubowski, S. Eckert and P. Fuchs. 1999. Biotechnological investigation for the prevention of marine biofouling II. Blue- green algae as potential producers of biogenic agents for the growth inhibition of microfouling organisms. Botanica Mar 42: 459-465.

2. Burja, A. M., B. Banaigs, E. Abou-Mansour, J. G. Burgess and P. C. Wright. 2001. Marine cyanobacteria - a prolific source of natural products. Tetrahedron, 57: 9347-9377.

3. Dahms, H. U., Y. Xu and C. Pfeiffer. 2006. Antifouling potential of cyanobacteria: a mini-review. Biofouling. 22: 317-327.

4. Difco Manual. 1984. Dehydrated Culture Media and Reagents for Microbiology, $10^{\text {th }}$ Edition, pp.689-691, Difco Laboratories Detroit Michigan 48232 U.S.A.

5. Desikachary, T. V. 1959. Cyanophyta. ICAR Monograph on Algae. ICAR, New Delhi, India.

6. Ghasemi, Y., A. Moradian, A. Mohagheghzadeh, S. Shokravi and M. H. Morowvat. 2007. Antifungal and antibacterial activity of the microalgae collected from paddy fields of Iran: characterization of antimicrobial activity of Chroococcus disperses. J. Biol. Sci., 7: 904-910.

7. Hardy, R. W. E., R. C. Burns and R. D. Holsten. 1973. Application of the acetylene-ethylene assay for measerment of nitrogn fixation. Soil Biol. Biochem., 5: 47-81. 
8. Lui, C. C., W. C. Wei and D. Y. Zheng. 1984. New Advances in Azolla Research and its Utilization in China; (Fuzhou, China: Fujian Academy of Agricultural Sciences)

9. Newton, J. W. and A. I. Herman. 1979. Isolation of cyanobacteria from the aquatic fern azolla. Arch. Microbiol., 120:161-165.

10. Pabby, A., S. Dua and A. S. Ahluwalia. 2000. Changes in nitrogen metabolism of Azolla microphylla and Azolla pinnata on supplementation of nitrogen fertilize. Phykos. 39:51-59.

11. Pabby, A., S. Dua and A. S. Ahluwalia. 2001. Change in ammonia-assimilating enzymes in response to different nitrate levels in Azolla pinnata and $A$. microphylla. J. Plant physiol., 158: 899-903.

12. Peters, G. A. and B. C. Mayne. 1974. The Azolla- Anabaena azollae relationship. Initial characterization of the association. Plant Physiol., 53:813-819.

13. Rippka, R., J. Deruelles, J. B. Waterburg, M. Herdman and R.Y. Stanier. 1979. Generic assignments, strain histories and properties of pure cultures of cyanobacteira. J. General Microbiol., 111: 1-16.

14. Subramanian, G. and P. Malliga. 1988. Isolation of Anabaena azollae from the megasporocarp of Azolla. Curr. Sci., 57:1352-1353.

15. Yoshida, S., D. A. Forno, J. H. Corck and K. A. Gomez. 1976. Laboratory Manual for Physiology Studies of Rice, Pp. 61-65. The International Rice Res. Inst. (IRRI), LoS Banos, Manila, Phlippines.

16. Zimmerman, W. J., B. H. Rosen and T. A. Lumpkin. 1989. Enzymatic, lectin and morphological characterization and classification of presumptive cyanobionts from Azolla Lam. NewPhytol., 113:497-503. 


\title{
صفات طحلب أنابينا أزولا المعزول من أزولا بيناتا
}

\author{
عزه احمد محمد عبد العال
}

معه بحوث الاراضسى والمباه و البيئه - مركز البحوث الزراعيه - الجبزة - مصر

تم عزل طحلب الأنابينا أزولا الذى يعيش معيشة تكافلية مع سرخس الازولا ( ازولا بيناتا ) و

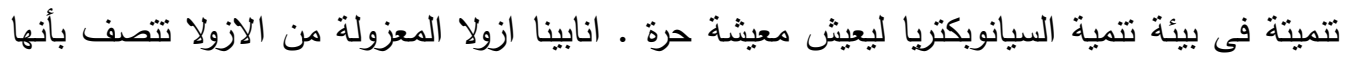

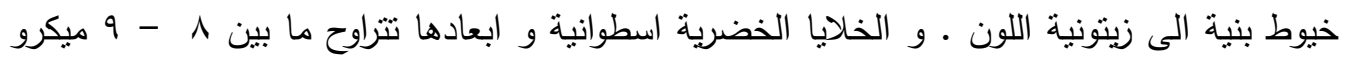

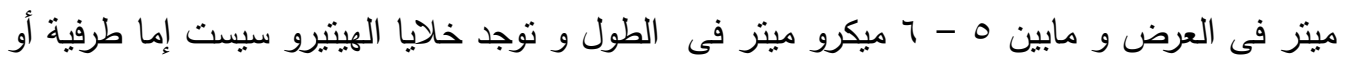

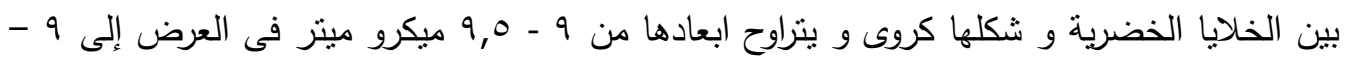
9,0 ميكرو ميثز فى الطول و يوجد بالخيط الجراثيم ( اكينينس) و هي اسطوانية الثكل و وينراوح

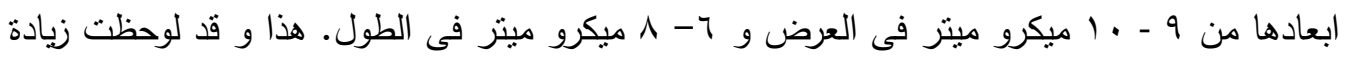

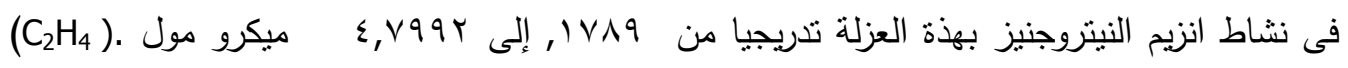

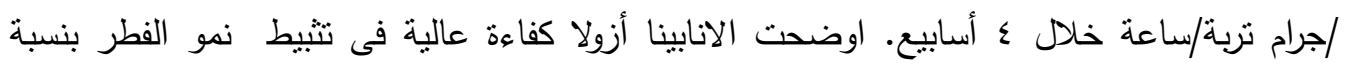

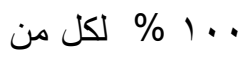

- (Alternaria alternate) , (Fusarium oxysporum) 